\title{
Research on Teaching Approach of Hurdle Race Technique Chungang Yi
}

Jiangxi Technical College of Manufacturing, office of board and lodging

\author{
Keywords: Hurdle race; Trail leg technique; Teaching optimization
}

\begin{abstract}
Hurdle race is a sprint event with strong technical requirements. It requires to cross certain fences of particular height and amounts in a certain distance. Since the training of trail leg technique is not enough with less special practice, this paper has conducted comprehensive analysis on the $110 \mathrm{~m}$-hurdle race technique with summary and analysis on existing defects and disadvantages as well as reasons. The result shows that average speed determines the hurdle race speed mainly, while hurdle race technique is another important factor. It has become a world trend to have fast hurdle speed and to run through the full distance with a high speed. The modern hurdle race techniques are characterized with short hurdle time, quick leg wagging, fast hurdle speed and small landing distance. It is helpful for improving hurdle race technique to have rational and stable hurdle distance.
\end{abstract}

\section{Introduction}

Hurdle race is a sprint event in track and field sports. It has had a over 100-year history since $100 \mathrm{~m}$-hurdle race was first listed in modern Olympic Games held in 1896. However, it has also experienced many revolutions from the initial "jumping hurdles" to "crossing hurdles" and to today's "hurdle race", which indicates that modern hurdle race is closer to sprint event.

Hurdle race is a sprint event in track and field sports. It is a asymmetrical periodical competitive even aiming to run through the full distance with high speed under certain restrictions. It requires higher demand for speed, strength and body flexibility and coordination. Regardless of form or connotation, hurdle race all has new changes and development. Faced with new teaching contents, hurdle race teaching should change its contents urgently to meet new trends and development.

Therefore, it is an important subject for hurdle race teaching to reform and explore new teaching approaches timely. At present, the current teaching contents and teaching means in hurdle race teaching are not adaptable to status, which has obviously affected and restricted students' mastery and understanding of hurdle race techniques and theories. Addressing this condition, initial experiment and discussion have been made in this paper.

\section{Defects and Disadvantages of Hurdle Race Techniques Existing in Current Action Teaching}

Hurdle Crossing is replaced by Hurdle Jumping. In the beginning, some athletes may hesitate because of poor psychological qualities. Thus, their body gravity may change with upward posture, which changes "hurdle crossing" into "hurdle jumping".

The Cross-Leg Action is Slow after Landing. During hurdle crossing, if the athlete can't control his headtrim well, that is, the center of body gravity move forward by body, then the center of gravity will land on the wagging leg, which will affect the later trail leg action, and thus affect the actual result directly.

The Center of Gravity is Unstable During Running. If the center of gravity is unstable during the hurdle race, then the athlete may perform badly. To find out the reason, it is because athletes are unsure about the three-step distance, so they may choose different ways to conduct the next action, and thus their original running speed may constantly decrease. 


\section{Analysis on the Teaching of Hurdle Race Technique}

Trail leg plays an important role in both hurdle race teaching and training, so it should obtain equal attention like other hurdle race technique. Addressing some teaching facts with relatively less exercise on trail leg, it is very necessary for them to create a series of special means and methods for trail leg training. Here are some ideas according to teaching practice.

Special exercise for crossing fences with bare-handed trail leg. It includes wagging exercise by holding ribs to cross fences of standard height. The ribs should lower than the fence (can use the replaced fence) so as to eliminate students' sense of fear with more confidence and better result.

Moving trail leg exercise. Bare-handed imitating practice can be adopted to cross fences of different heights.

Moving trail leg to cross several fences on the side, which aims to practice quick lift action.

Moving trail leg to cross several fences. Replaced fences of different heights can be used to practice hurdles.

Bare-handed moving hurdle race. It aims to practice the coordination between trail leg, wagging leg as well as two arms.

Running between fences. Cross one or several hurdles to understand the coordination between two legs and two arms. (The height can be firstly lower than the standard height with replaced fence, and then turn to standard height).

Practice crossing hurdles of standard height and standard distance. The trainers can begin with four or five hurdles and increase the amounts gradually till they can finish the whole exercise.

Create a series of special exercise for trail leg hurdle race including induced exercise and imitating exercise so that students can form correct trail leg hurdle race technique. It aims to help students to form correct trail leg hurdle race technique, which can be done during preparation activities or seen as special exercise means.

\section{Analysis on the Effect of Optimized Teaching on Students' Learning Effect}

First, with structure-orientation teaching theory, optimized teaching combines motion image with motion words for students so as to establish an action-learning psychological frame for hurdle race technique, within which internal adjustment mechanism and psychological energy can be aroused to complete correct motion technique, and thus students can define motion goals as well as psychological motion procedures for motion technique during the training. By this way, students can pay more attention to the speed, high center of gravity and high frequency and so on during hurdle race learning.

Besides, with programmed teaching, optimized teaching can not only mobilize students' activeness, but also provide sound conditions for students' other practice tasks. In addition, timely feedback of learning effect can improve students' initiative, activeness and self-consciousness more effectively with better abilities of problems analysis and resolution. More importantly, optimized teaching can correct errors in each class timely through programmed teaching and timely feedback, which has effectively held various deviated phenomena and achieved a best control of teaching process. Meanwhile, the complicated and variable hurdle race technique becomes more scientific and rational, and thus it can ensure a optimum teaching with relatively higher efficiency.

\section{Conclusion}

Hurdle race technology is a relatively complex technical sport, which has higher requirements for speed, strength, flexibility and coordination; and meanwhile athletes should have quite sound psychological qualities. While training hurdle race skills, the coaches should firstly define the orders and main points of hurdle race, and then train athletes from simple to complex gradually. In this paper, it mainly talks about the techniques, related theories, special exercises and quality exercise methods of first trailing leg technique. Although the current hurdle race training pays less attention to first trailing leg technique compared o other training sections and teaching approaches, 
this paper aims to develop a balanced education on hurdle race technique so that students can achieve a coordinated and balanced development as well as a sound sports result with comprehensive mastery of hurdle race technique. Therefore, during teaching and training, coaches should fully understand the important role of first trailing leg with specific training on students' existing problems according to their performance so as to achieve sound teaching effect.

\section{References}

[1] Gómez P L, Weltichanes J, Alzamora S M. Hurdle technology in fruit processing. [J]. Review of Food Science \& Technology, 2011, 2:447-465.

[2] Mukhopadhyay S, Gorris L G M. Hurdle Technology [J]. Encyclopedia of Food Microbiology, 2014(6):221-227.

[3] Leistner B L. Principles and applications of hurdle technology, p. 1-21[C]// methods of food preservation. Blackie Academic and Professional. 2010.

[4] Rahman M S. Hurdle Technology in Food Preservation [J]. Food Engineering, 2015:17-33.

[5] Shalini R, Singh S. Effect of Hurdle Technology in Food Preservation: A Review.[J]. Critical Reviews in Food Science \& Nutrition, 2014:0-0.

[6] Leistner L. Further developments in the utilization of hurdle technology for food preservation [J]. Journal of Food Engineering, 1994, 22(94):421-432.

[7] Rahman M S. Hurdle Technology in Food Preservation [J]. Food Engineering, 2015:17-33.

[8] Chawla S P, Chander R, Sharma A. Safe and shelf-stable natural casing using hurdle technology [J]. Food Control, 2006, 17(2):127-131.

[9] Karthikeyan J, Kumar S, Anjaneyulu A S, et al. Application of hurdle technology for the development of Caprine keema and its stability at ambient temperature.[J]. Meat Science, 2000, 54(1):9-15.

[10]Leistner L. Hurdle Technology Applied to Meat Products of the Shelf Stable Product and Intermediate Moisture Food Types[M]// Properties of Water in Foods. Springer Netherlands, 1985:309-329.

[11]Chawla S P, Chander R. Microbiological safety of shelf-stable meat products prepared by employing hurdle technology [J]. Food Control, 2004, 15(7):559-563.

[12]M. Shimokomaki, B. D. G. M. Franco, T. M. Biscontini, et al. Charqui meats are hurdle technology meat products [J]. Food Reviews International, 1998, 14(4):339-349. 